\title{
Physicochemical and sensory characteristics of reduced sugar starfruit juice
}

\author{
Prasetijo, L.D., ${ }^{*}$ Trisnawati, C.Y. and Srianta, I. \\ Department of Food Technology, Widya Mandala Catholic University Surabaya, Jalan Dinoyo 42-44 \\ Surabaya, East Java, Indonesia 60265
}

\begin{abstract}
Article history:
Received: 16 May 2017

Received in revised form:

26 June 2017

Accepted: 27 June 2017

Available Online: 27 June

2017
\end{abstract}

Keywords:

Starfruit,

Juice,

Cane sugar,

Sorbitol,

Reduced-sugar

DOI:

http://doi.org/10.26656/

fr.2017.4.053

\begin{abstract}
The objective of this research was to study the physicochemical and sensory characteristics of reduced sugar starfruit juice. Cloudy starfruit juice produced by juicing of the edible part of starfruit, then the obtained filtrate was formulated with citric acid, Na$\mathrm{CMC}$ and different ratio of cane sugar and sorbitol i.e. 10.0\%:0.0\%, 7.5\%:2.5\%, 5.0\%:5.0\%, 2.5\%:5.0\% and 0.0\%:10.0\% (\% b/v). Physicochemical characteristics of the starfruit juice were total soluble solids in a range of 9.20 and $11.90 \%$, the viscosity of 8.27 and $8.65 \mathrm{cP}, \mathrm{pH}$ of 3.56 and 3.63; and titratable acidity of 0.29 and $0.31 \%$. Those cane sugar and sorbitol ratios affected significantly only on the total soluble solids. Based on the sensory evaluation, starfruit juice with cane sugar and sorbitol ratio of $7.50 \%: 2.50 \%$ had the highest total preference scores of color, appearance, and taste. Colloidal stability of the starfruit juices during 10 days storage was in a range of $86.26 \%$ and $88.18 \%$.
\end{abstract}

\section{Introduction}

Starfruit (Averrhoa carambola) is one of the tropical fruits and produced largely in South East Asian countries. Indonesia is one of the biggest producers with a production level of 81,653 tones in 2014 (Kementerian Pertanian, 2015). Starfruit is rich in vitamins, minerals, sugars, and fibers (Moreschi et al., 2007). It is usually used to treat headaches, vomiting, coughing, and hangover, as an appetite stimulant, diuretic, antidiarrheal and febrifugal agent (Cabrini et al., 2011). Starfruit is usually consumed fresh. The high moisture content, about $90 \%$ of fresh weight, make starfruit easy to lose its quality. One of effort to preserve the perishable fruit is processing it to become fruit juice and other products (Campbell et al., 1989; Barret et al., 2005; Wu et al., 2005).

Currently, obesity and diabetes mellitus prevalence is increasing. Diet of reduced sugar and low sugar foods and beverages is an effort to prevent and control the obesity and diabetes. In general, cane sugar is used as the sweetener of fruit juice because of its availability, economic and relatively higher sweetness than other sugars. Cane sugar level in fruit juice formula depends on the fruit juice type. Low-calorie sweeteners have been studied to develop low-calorie or reduced sugar food products (Parpinello et al., 2001; Porto et al., 2004). Sorbitol is a low-calorie sugar alcohol and natural sweetener, which is including in GRAS (Generally Recognize as Safe). Sorbitol, also known as glucitol, is a low-calorie sugar alcohol and natural sweetener with a sweet taste which the human body metabolizes slowly. It can be obtained by reduction of glucose, changing the aldehyde group to a hydroxyl group. Most Sorbitol is made from corn syrup, but it is also found in apples, pears, peaches, and prunes. Sorbitol is a sugar substitute with approximately $60 \%$ the sweetness of sucrose (Ansari et al., 2015). Their solubility in water are 0.769 and $0.701 \mathrm{~g} / \mathrm{g}$ solution respectively for sorbitol and sucrose (Bouchard et al., 2007).

This research objective was to study the physicochemical and sensory characteristics of reduced sugar starfruit juice at different cane sugar and sorbitol ratio.

\section{Materials and methods}

\subsection{Materials}

Ripe starfruit was obtained from local market with characteristics of yellow, length about $15 \mathrm{~cm}$ and weight in a range of 200 gram and 250 gram. Cane sugar 
(crystal form) and sorbitol (liquid form with concentration of $70 \% \mathrm{w} / \mathrm{v}$ ) were purchased from local market.

\subsection{Processing of starfruit juice}

After washing, the non-edible parts of starfruit were removed. The edible part was cut and steam blanched at $90^{\circ} \mathrm{C}$ for 3 minutes, then crushed with water addition and filtered. About $1.2 \mathrm{~L}$ of filtrate was formulated with citric acid, Na-Carboxymethylcellulose (Na-CMC) and different ratio of cane sugar and sorbitol i.e. 10.0\%:0.0\%, 7.5\%:2.5\%, 5.0\%:5.0\%, 2.5\%:5.0\% and $0.0 \%: 10.0 \% \quad(\% \mathrm{~b} / \mathrm{v})$. After that, the juice was pasteurized at $85^{\circ} \mathrm{C}$ for 10 minutes, and packed in a bottle. The product was ready to drink cloudy starfruit juice.

\subsection{Physicochemical analysis}

Physicochemical characteristics of the cloudy starfruit juice including total soluble solids, viscosity, $\mathrm{pH}$ and titratable acidity. Total soluble solids was measured by using a portable refractometer (Toto PR-F), viscosity by a viscometer (Brookfield model DV-E) with spindle 1 and minimum accuracy of $95 \%$, and $\mathrm{pH}$ by a $\mathrm{pH}$ meter (Manual pH meter Micro Bench TI 2100). Titratable acidity was measured according to Rangana (1977) by using direct titration with $\mathrm{NaOH}$ solution of $0.1 \mathrm{~N}$ and phenol-phtalein indicator. Titratable acidity was expressed as \% oxalic acid.

\subsection{Sensory evaluation}

Consumer preference method was used for sensory evaluation of the starfruit juice. 90 panelists, who are familiar with the fruit juice, were requested to give a score of color, appearance and taste preference of the starfruit juice. Panelists gave a score with a scale of 1-7, in which 1 represent dislike extremely to 7 represent like extremely. The test was conducted in sensory evaluation room.

\subsection{Colloidal stability measurement}

The colloidal stability of starfruit juice was measured according to Anuru (2005). $150 \mathrm{~mL}$ of starfruit juice samples were stored at room temperature for 10 days. Changes in colloidal stability were indicated by precipitate formation. The level of precipitates of starfruit juice was observed on days 0,5 and 10 . Colloidal stability was expressed as \% precipitation. Higher \% precipitation indicates lower colloidal stability. $\%$ precipitation was calculated by using below equation:

$$
\% \text { precipitation }=\frac{\text { precipitate }(\mathrm{ml})}{150 \mathrm{ml}} \times 100 \%
$$

\subsection{Statistical analysis}

The obtained triplicate data were analysed using Analysis of Variance with $\alpha=5 \%$ and Duncan's Multiple Range Test with $\alpha=5 \%$.

\section{Results and discussion}

\subsection{Physicochemical characteristics}

Table 1. Physicochemical characteristics of starfruit juice at different cane sugar: sorbitol ratio

\begin{tabular}{ccccc}
\hline $\begin{array}{c}\text { Cane } \\
\begin{array}{c}\text { Sugar : } \\
\text { Sorbitol }\end{array}\end{array}$ & $\begin{array}{c}\text { Total soluble } \\
\text { solids }(\%)\end{array}$ & $\begin{array}{c}\text { Viscosity } \\
(\mathrm{cP})\end{array}$ & $\mathrm{pH}$ & $\begin{array}{c}\text { Total } \\
\text { acidity } \\
(\%)\end{array}$ \\
\hline $10.0: 0.0$ & $11.90^{\mathrm{a}}$ & $8.65^{\mathrm{a}}$ & $3.63^{\mathrm{a}}$ & $0.29^{\mathrm{a}}$ \\
$7.5: 2.5$ & $11.20^{\mathrm{b}}$ & $8.53^{\mathrm{a}}$ & $3.57^{\mathrm{a}}$ & $0.30^{\mathrm{a}}$ \\
$5.0: 5.0$ & $10.75^{\mathrm{c}}$ & $8.53^{\mathrm{a}}$ & $3.60^{\mathrm{a}}$ & $0.30^{\mathrm{a}}$ \\
$2.5: 7.5$ & $9.65^{\mathrm{d}}$ & $8.62^{\mathrm{a}}$ & $3.58^{\mathrm{a}}$ & $0.30^{\mathrm{a}}$ \\
$0.0: 10.0$ & $9.20^{\mathrm{e}}$ & $8.27^{\mathrm{a}}$ & $3.56^{\mathrm{a}}$ & $0.31^{\mathrm{a}}$ \\
\hline
\end{tabular}

Note: different character in the same column indicate different significantly at $\alpha=5 \%$

Table 1 shows the data of total soluble solids, viscosity, $\mathrm{pH}$, and titratable acidity of cloudy starfruit juice at a different ratio of cane sugar and sorbitol. Total soluble solids of starfruit juice were in a range of $9.20 \%$ and $11.90 \%$. Those total soluble solids contents were similar to that reported by Minh (2014) of $9.21 \%$ but higher than that of total soluble solids reported by Anim and Tano-Debrah (2004) of 5.9\%. Moreschi et al. (2007) reported that starfruit contains vitamins, minerals, sugars, and fibers. The water soluble vitamins, minerals, sugars and water soluble fibers might be extracted during the juicing process. In this research, the total soluble solids source is not only the starfruit but also ingredients added into the juice i.e. Na-CMC, citric acid, cane sugar and sorbitol dispersed in the juice system and may contribute to the total soluble solids. Based on the data analysis, the ratio of cane sugar and sorbitol affected on the $\%$ total soluble solids significantly. Lower cane sugar portion, the total soluble solids tends to lower. This may because cane sugar used was in crystal form which contains sucrose more than $90 \%$, whereas sorbitol in liquid form contains $70 \%$ of sorbitol.

The viscosity of starfruit juice at a different ratio of cane sugar and sorbitol were in a range of $8.27 \mathrm{cP}$ and $8.65 \mathrm{cP}$. Chemical compounds of filtrate especially water soluble fibers and sugars, and $\mathrm{Na}-\mathrm{CMC}$ added seems 
become the major components which contribute to the viscosity. Siti Mazlina et al. (2008) reported that removing pectin through enzymatic hydrolysis resulted in clear starfruit juice with the low viscosity of 1.3-1.4 cP, which indicated that pectin contributes to the viscosity. Those cane sugar and sorbitol ratios did not affect the viscosity of the starfruit juice. The viscosity of a colloidal dispersion of solid particles in sugar solution depends on three types of interactions: particle-particle, particle-water, and particle-sugar (Benitez et al., 2009). At the ratio of cane sugar and sorbitol applied to the formulation may not affect significantly on those interactions.

$\mathrm{pH}$ and titratable acidity were in a range of 3.56 and 3.63; and $0.29 \%$ and $0.31 \%$, respectively. Those $\mathrm{pH}$ of the starfruit juice were higher than that reported by Anim and Tano-Debrah (2004) of 2.2, but lower than reported by Minh (2014) of 4.3. Consistently, the titratable acidity was lower than that reported by Anim and Tano-Debrah (2004) of $0.66 \%$. pH and titratable acidity of the juice depend on the ripeness of the starfruit and other ingredients added especially organic acids. In this research, citric acid was used in the juice formulation. Based on the analysis of variance, the ratio of cane sugar and sorbitol did not affect the $\mathrm{pH}$ and total acidity values of starfruit juice. This might be due to the slightly different $\mathrm{pH}$ values of both materials. According to the specification of sorbitol and cane sugar, the $\mathrm{pH}$ values were 6.91 and 7.00 , respectively.

\subsection{Sensory characteristics}

Table 2. Preference score starfruit juice at different ratio of cane sugar: sorbitol

\begin{tabular}{cccc}
\hline $\begin{array}{c}\text { Cane Sugar : } \\
\text { Sorbitol }\end{array}$ & Color & Appearance & Taste \\
\hline $10.0: 0.0$ & $5.33^{\mathrm{a}}$ & $5.07^{\mathrm{a}}$ & $5.22^{\mathrm{a}}$ \\
$7.5: 2.5$ & $5.07^{\mathrm{a}}$ & $5.20^{\mathrm{a}}$ & $5.50^{\mathrm{b}}$ \\
$5.0: 5.0$ & $4.95^{\mathrm{b}}$ & $4.78^{\mathrm{ab}}$ & $4.56^{\mathrm{c}}$ \\
$2.5: 7.5$ & $4.34^{\mathrm{bc}}$ & $4.66^{\mathrm{bc}}$ & $3.94^{\mathrm{d}}$ \\
$0.0: 10.0$ & $4.29^{\mathrm{c}}$ & $4.76^{\mathrm{c}}$ & $3.34^{\mathrm{d}}$ \\
\hline
\end{tabular}

Note: different character in the same column indicate different significantly at $\alpha=5 \%$

Results of the sensory evaluation of the reduced sugar starfruit juice were shown in Table 2. The color is one of the factors that could affect consumer preferences for the products. High sorbitol portion tends to produce pale starfruit juice. It might be due to sorbitol does not cause Maillard reaction. Appearance is also one of the factors that influence consumer preference in addition to color. The appearance of the juice was evaluated for the turbidity level. Different ratio of cane sugar and sorbitol affected significantly the appearance of reduced sugar starfruit juice.

The ratio of cane sugar and sorbitol affected significantly the taste score of reduced sugar starfruit juice. Higher sorbitol level caused lower taste preference score of the juice. Comments from panelists showed that the taste of juice without cane sugar was too sour, which might be due to the level of sweetness of sorbitol is a $60 \%$ of the sweetness of sucrose. In addition, lower cane sugar caused higher astringency. This might be due to the sweetness of cane sugar provide a masking effect to the astringency. Based on total scores, the ratio of cane sugar and sorbitol of $7.5 \%$ and $2.5 \%$ produced reduced starfruit juice with the highest preference.

\subsection{Colloidal stability}

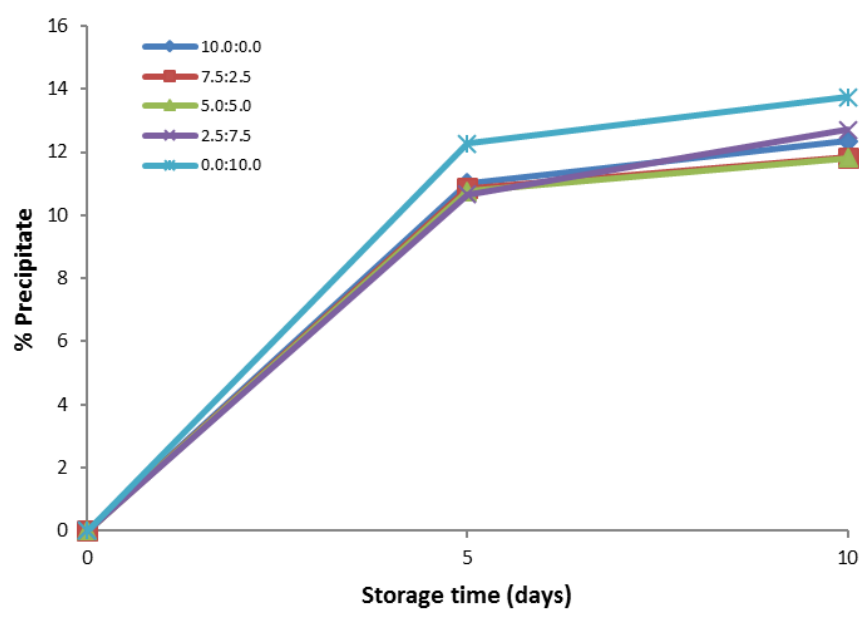

Figure 1. Colloidal stability of starfruit juice during storage

Figure 1 shows the colloidal stability of starfruit juice during storage. Percentage of precipitation of the juices during 10 days storage was in a range of $11.82 \%$ and $13.74 \%$, its mean that the colloidal stability in a range of $86.26 \%$ and $88.18 \%$. The colloidal stabilities of the cloudy starfruit juices were higher than cloudy apple juices reported by Telescko et al. (2016) in a range of $18.07 \%$ and $34.43 \%$ measured from the turbidity during 7 days storage. The starfruit juice with the highest portion of sorbitol had the highest percentage of precipitation, whereas other ratios had similar stability. The colloidal stability is a complex mechanism which depends on the type of particles, particle sizes and interactions in the cloudy fruit juice system (Benitez et al., 2009; Teleszko et al., 2016). Benitez et al. (2009) suggested a model of fruit juice stability (as total energy barrier of the system) to be the sum of a particle-particle interaction (including particle-water interaction) contribution plus a particle-sugar contribution. 


\section{Conclusion}

The starfruit juices had physicochemical characteristics: total soluble solids in a range of 9.20 and $11.90 \%$; viscosity of 8.27 and $8.65 \mathrm{cP}, \mathrm{pH}$ of 3.56 and 3.63; and titratable acidity of 0.29 and $0.31 \%$. Different ratio of cane sugar and sorbitol ratios affected significantly only on the total soluble solids, higher sorbitol portion produced lower total soluble solids. Starfruit juice with cane sugar and sorbitol ratio of 7.50\%:2.50\% had the highest total preference scores. Colloidal stability of the starfruit juices during 10 days storage was in a range of $86.26 \%$ and $88.18 \%$. Further research on the evaluation of health effect of the reduced sugar starfruit juice is recommended.

\section{References}

Anim, G. and Tano-Debrah, K. (2004). Suitability of carambola (Averrhoa carambola) fruit juice as a substrate for wine fermentation. African Journal of Food, Agriculture, Nutrition and Development 4(2). doi: http://dx.doi.org/10.4314/ajfand.v4i2.19165

Ansari, A.R.M., Mulia, S.J. and Pramod, G.J. (2015). Review on artificial sweeteners used in formulation of sugar free syrups. International Journal of Advances in Pharmaceutics, 4(2), 5-9.

Anuru, F. H. (2005). Penggunaan Gum Xanthan Sebagai Stabilizer dalam Jus Jambu Biji. Surabaya: Fakultas Teknologi Pertanian Universitas Katolik Widya Mandala Surabaya.

Barret, D.M, Somogyi, L. and Ramaswamy, H. (2005). Processing Fruit Science and Technology. $2^{\text {nd }} e d$. New York: CRC Press

Benitez, E.I., Genovese, D.B. and Lozano, J.E. (2009). Effect of typical sugars on the viscosity and colloidal stability of apple juice. Food Hydrocolloids, 23(2), 519-525.

Bouchard, A.A., Hofland, G.W. and Witkamp, G.J. (2007). Properties of sugar, polyol, and polysaccharide water-ethanol solutions. Journal of Chemical Engineering Data, 52, 1838-1842.

Cabrini, D.A., Moresco, H.H., Imazu, P., da Silva, C.D., Pietrovski, E.F., Mendes, D.A.G.B., Prudente, A.D.S., Pizzolatti, M.G., Brighente, I.M.C. and Otuki, M.F. (2011). Analysis of the potential topical anti-inflammatory activity of Averrhoa carambola L. in mice. Evidence-Based Complementary and Alternative Medicine, 2011, 1-7. doi:10.1093/ecam/ neq026

Campbell, C.A. and Koch, K.E. (1989). Sugar / acid composition and development of sweet and tart carambola fruit. Journal of the American Society for Holticultural Science, 114(3), 455-457.

Kementerian Pertanian (2015). Statistik Produksi Hortikultura Tahun 2014. Direktorat Jenderal Hortikultura, Kementerian Pertanian. Retrieved from: http:/hortikultura.pertanian.go.id/wp-content/ uploads/2016/02/Statistik-Produksi-2014.pdf

Minh, N.P. (2014). Utilization of ripen starfruit for vinegar fermentation. International Journal of Multidisciplinary Research and Development, 1(4), 82-93.

Moreschi, S.R.M., Limonta, C.R., Marques, M., Morgano, O.M.M.A. and Parra, E.S.B. (2007). Centesimal/nutritional characterization of acerola and starfruit. Magistra, 19(4), 379-385.

Parpinello, G. P., Versari, A., Castellari, M. and Galassi, S. (2001). Stevioside as a replacement of sucrose in peach juice: sensory evaluation. Journal of Sensory Studies, 16(5), 471-484.

Porto, C.D, Cordaro, F. and Marcassa, N. (2004). Effects of carbohydrate and noncarbohydrate sweeteners on the orange spirit volatile Compounds. LWT - Food Science and Technology, 39(2), 159165.

Rangana, S. (1977). Handbook of analysis and quality control for fruit and vegetable products. New Delhi: Mc. Graw-Hill Publishing Company

Siti Mazlina, M.K, Abdul Ghani, L.A., Nur'Aliaa, A.R., Siti Aslina, H. and Rozita, O. (2008). Comparison on optimization of starfruit juice using RSM between two Malaysian starfruit varieties (B11 and B10). Pertanika Journal of Science and Technology, 16(1), 1-13.

Teleszko, M., Nowicka, P. and Wojdylo, A. (2016). Chemical, enzymatic and physical characteristic of cloudy apple juices. Agricultural and Food Science, 25, 34-43.

Wu, J.S., Wu, M.C., Jiang, C.M., Hwang, Y.P., Shen, S.C. and Chang, H.M. (2005). Pectinesterase inhibitor from jelly-fig (Ficus awkeotsang Makino) achenes reduces methanol content in carambola wine. Journal of Agricultural and Food Chemistry, 53(24), 9506-9511. 